http://jmscr.igmpublication.org/home/ ISSN (e)-2347-176x ISSN (p) 2455-0450 crossref DOI: https://dx.doi.org/10.18535/jmscr/v9i4.01

\title{
ABO and Rh (D) Phenotypes, Allele Frequencies and Estimated Genotypes in Omanis: A Retrospective Study from Armed Forces Hospital
}

\author{
Authors \\ Mujtaba Allawati ${ }^{1}$, Laila Al-Kalbani ${ }^{2}$, Tufaila Al-Balushi ${ }^{3}$ \\ ${ }^{1}$ Dept. of Medical Laboratory Science, Oman Collage of Health Sciences, Sultanate of Oman \\ ${ }^{2}$ Dept. of Medical Laboratory, Armed Forces Hospital Al Khoudh, Sultanate of Oman
}

\begin{abstract}
Frequencies of $A B O$ and $R h(D)$ groups vary throughout the world due to ethnic diversity. The distribution may also vary across country areas due to different ethnic groups. Oman is a genetically admixed population country consisting of African, Caucasian and Asian ancestries. Due to frequencies variation throughout the world and lack of study in Oman, this propelled us to determine the phenotypes and estimate the genetic variability of $A B O$ and $R h(D)$ blood groups in the Omani population. This retrospective study concerning $A B O$ and $R h(D)$ blood groups of a small section of the Omani population was undertaken between January 2017 and December 2017. The data were reviewed and calculations performed to determine ABO and Rh (D) phenotypes, allele frequencies and genotypes estimation. The results were compared with other populations.

Three thousand four hundred and sixteen (3416) blood donors' data from Armed Forces Hospital blood bank were collected. Overall distribution of ABO group in Omanis is; group O (50.47\%), group A (24.06\%), group $B(21.63 \%)$ and group $A B(3.83 \%)$, whereas distribution of $R h(D)$ positive and $R h(D)$ negative is $91.65 \%$ and $8.35 \%$ respectively. Allelic frequency of $A, B, O, D$ and $d$ is $0.15,0.14,0.710 .71$ and 0.29 respectively. Genotype frequencies recorded as $(A A=0.0225, A O=0.213, B B=0.0196, B O=0.1988, A B$ $=0.042, O O=0.5041, D D=0.5057, D d=0.411$ and $d d=0.0833)$. The commonest $A B O$ blood group in Omanis is $O$ group while the $A B$ group is the rarest with the sequence $O>A>B>A B$. The recorded frequencies appear to be intermediate between some other countries and different to some other Middle East regions including Arabs.
\end{abstract}

Keywords: $A B O / R h$ blood group, $A B O$ allele, $A B O$ genes, RHD genes, allele frequency, Omani population.

\section{Introduction}

Data on $\mathrm{ABO}$ and $\mathrm{Rh}$ group distribution can be very helpful for blood bank management and safe transfusion. Knowledge on blood group frequency for different blood group antigens can be of great help on how easy is to find the matching blood units especially for recipients who require multiple transfusions. These data can also be useful in population genetics study and its association to various diseases in the population ${ }^{1-5}$. These blood groups have also noted to be prognostic biomarkers for various cancers ${ }^{6-8}$. Though individuals share the same blood group systems, but the frequency of specific blood type varies in the population. Prevalence of $\mathrm{ABO}$ and $\mathrm{Rh}$ groups vary throughout the world due to ethnic diversity ${ }^{9}$. The distribution may also vary across country areas due to different ethnic groups ${ }^{10}$. The prevalence and frequencies of 
$\mathrm{ABO}$ and $\mathrm{Rh}$ groups have been largely studied in different populations including Arabs ${ }^{11-16}$. Oman is a Gulf country with a total population of about two million $^{17}$ admixed of Asian, African and Caucasian $^{18}$. A 30 years old study on 160 healthy Omanis conducted by Danubio and colleague showed the following $\mathrm{ABO} \& \mathrm{Rh}$ (D) allele frequencies $(A=0.164, B=0.110, O=0.726, D=$ 0.738 and $d=0.262)^{19}$. However, larger sample size can be very useful for better accuracy of statistical confidence level on frequencies and distribution. Another study on 1251 Omani pregnant in Sultan Qaboos University Hospital recorded decreasing ABO types order as $\mathrm{O}(52.2 \%)>\mathrm{A}(26.5 \%)>\mathrm{B}$ $(16.3 \%)>\mathrm{AB}(5.1 \%)^{18}$. However, this study was limited to one gender only. A recent study by AlRiyami and colleagues on 337 Omani blood donors showed most common blood group was $\mathrm{O}+(44.9 \%)$ followed by $\mathrm{B}+(20.2 \%), \mathrm{A}+(17.4 \%), \mathrm{AB}+(6.8 \%)$, B- $(2.7 \%)$, O- $(7.4 \%)$, and A- $(0.6 \%)^{20}$. However; the sample size in Al-Riyami et al study gives confidence interval (C.I) of 5.36 compared to our study with 1.68 C.I. In addition, the study did not calculate the allele frequencies compared to our study. To our best knowledge, there are no other studies, which have published the $\mathrm{ABO}$ and $\mathrm{Rh}$ group and allele frequencies for Omanis. In our study, distribution of $\mathrm{ABO}$ and $\mathrm{Rh}$ (D) phenotypes and allele frequencies have been studied based on retrospective data of Armed Forces Hospital (AFH) blood bank donors.

\section{Methods}

A retrospective study was conducted at the Armed Forces Hospital (AFH) Al Khoudh under Ministry of Defence Oman. Ethical approval was obtained from Forces Medical Services Research Committee (FMS-RC) and Gatekeeper consent form was provided to the AFH laboratory management prior to data access. ABO and Rh (D) blood group data for 3416 male and female > 18 years old Omani donors were collected during a one-year period between January and December 2017. Ethylenediaminetetraacetic acid (EDTA) vacutainer was used for samples collection and BioRad gel card haemagglutination method was used for the phenotyping according to manufacturer's instructions.

$\mathrm{ABO}$ and $\mathrm{Rh}$ Phenotypes were calculated as percentage by dividing number of specific blood type by total number of samples times 100. $A B O$ and $R H D$ allele frequencies were determined using Hardy-Weinberg law by the following equations, where $\mathrm{p}, \mathrm{q}, \mathrm{r}, \mathrm{s}$ and t represent $A, B, O, d$ and $D$ alleles respectively:

$$
\mathrm{p}=1-\sqrt{ }(\mathrm{B}+\mathrm{O}), \mathrm{q}=1-\sqrt{ }(\mathrm{A}+\mathrm{O}), \mathrm{r}=\sqrt{\mathrm{O}}, \mathrm{s}=\sqrt{\mathrm{dd}}, \mathrm{t}=1-\mathrm{s}
$$

Chi-square test of independence (Two-way Contingency Table) was performed to calculate $p$ value and determine the significance of $\mathrm{ABO}$ and RHD blood types distribution and frequency in Omanis compared with other populations.

\section{Results}

The three thousand four hundred and sixteen (3416) Omani donors consist of 3308 males and 108 females. The frequency of overall $\mathrm{ABO}$ types distribution pattern was found to be $\mathrm{O}(50.47 \%)>\mathrm{A}$ $(24.06 \%)>\mathrm{B}(19.29 \%)>\mathrm{AB}(3.62 \%)$. Among $\mathrm{ABO} \mathrm{Rh}(\mathrm{D})$ positive males and $\mathrm{Rh}$ (D) negative females, the distribution was noted to be the same as overall pattern, whereas it observed to be different decreasing pattern as $\mathrm{O}>\mathrm{B}>\mathrm{A}>\mathrm{AB}$ among $\mathrm{Rh}$ (D) negative males and Rh (D) positive females. Among $\mathrm{Rh}$ (D) blood groups, $91.65 \%$ were recorded to be positive and $8.35 \%$ were negative. The decreasing order of ABO allele frequency among Omanis is $O$ (0.71) followed by allele $A(0.15)$ and allele $B(0.14)$. In Rh (D), the frequency is 0.71 for allele $D$ and 0.29 for $d$. The estimated genotype frequencies recorded as $A A=0.0225, A O=0.213, B B=0.0196$, $B O=0.1988, A B=0.042, O O=0.5041, D D=$ $0.5057, D d=0.411$ and $d d=0.0833$

The entire document should be in Times New Roman of font size 10.Other font types may be used if needed for special purposes. 
Table 1. ABO and Rh (D) types comparison between Omanis and other populations

\begin{tabular}{|c|c|c|c|c|c|c|c|}
\hline & \multicolumn{4}{|c|}{ ABO type (\%) } & \multicolumn{2}{|c|}{ Rh (D) type (\%) } & \multirow[t]{2}{*}{ Reference(s) } \\
\hline Study & $\mathrm{O}$ & $\mathrm{A}$ & $\mathrm{B}$ & $\mathrm{AB}$ & Positive & Negative & \\
\hline Present & 50.47 & 24.06 & 21.63 & 3.83 & 91.65 & 8.35 & $\begin{array}{l}\text { Present } \\
\text { study }\end{array}$ \\
\hline Saudi Arabia & 56.8 & 33.4 & 6 & 3.8 & 92.8 & 7.2 & [13] \\
\hline Kuwait & 44.6 & 26.7 & 24.1 & 4.6 & $\mathrm{NT}^{*}$ & $\mathrm{NT}^{*}$ & [22] \\
\hline $\begin{array}{l}\text { Kurdistan } \\
\text { (Iraq) }\end{array}$ & 37.16 & 32.47 & 23.84 & 6.53 & 91.73 & 8.27 & [23] \\
\hline Bahrain & 53.4 & 19.43 & 23.1 & 4.07 & 92.82 & 7.18 & [24] \\
\hline Tanzania & 52 & 26 & 19 & 3 & 98 & 2 & [12] \\
\hline $\begin{array}{l}\text { Iran } \\
\text { (Khuzestan) }\end{array}$ & 40.21 & 28.48 & 24.71 & 6.6 & 92.38 & 7.62 & [25] \\
\hline $\begin{array}{l}\text { Eastern India } \\
\text { (Jharkhand) }\end{array}$ & 34.73 & 22.09 & 35.15 & 8.03 & 96.46 & 3.54 & [26] \\
\hline $\begin{array}{l}\text { Northern } \\
\text { India } \\
\text { (Punjab) }\end{array}$ & 34.31 & 18.01 & 38.06 & 9.62 & 91.28 & 8.72 & [27] \\
\hline Palestine & 32.9 & 39.29 & 21.33 & 6.48 & 97.32 & 2.68 & [28] \\
\hline Jordan & 36.62 & 38.36 & 18.04 & 6.98 & $\mathrm{NT}^{\mathrm{a}}$ & $\mathrm{NT}^{*}$ & [29] \\
\hline
\end{tabular}

${ }^{a}$ NT: Not tested

Table 2. ABO and Rh (D) allele frequencies in Omanis compared to other populations

\begin{tabular}{lcccccc}
\hline \multirow{2}{*}{ Population } & \multicolumn{3}{c}{ Allele frequencies } & & & \\
\cline { 2 - 6 } & $A$ & $B$ & 0 & $D$ & $d$ & Reference \\
\hline Oman & 0.15 & 0.14 & 0.71 & 0.71 & 0.29 & Present study \\
Oman historic study & 0.164 & 0.11 & 0.726 & 0.738 & 0.262 & {$[19]$} \\
Kuwait & $0.177^{\mathbf{b}}$ & $0.155^{\mathbf{a}}$ & $0.668^{\mathbf{b}}$ & $\mathrm{NT}^{\mathbf{c}}$ & $\mathrm{NT}^{\mathbf{c}}$ & {$[22]$} \\
Saudi Arabia & $0.197^{\mathbf{b}}$ & $0.039^{\mathbf{b}}$ & $0.764^{\mathbf{b}}$ & 0.732 & 0.268 & {$[13]$} \\
Switzerland & $0.29^{\mathbf{b}}$ & $0.073^{\mathbf{b}}$ & $0.637^{\mathbf{b}}$ & $0.613^{\mathbf{b}}$ & $0.387^{\mathbf{b}}$ & {$[30]$} \\
Tanzania & 0.159 & $0.12^{\mathbf{a}}$ & 0.721 & $0.848^{\mathbf{b}}$ & $0.152^{\mathbf{b}}$ & {$[12]$} \\
Pakistan & $0.183^{\mathbf{b}}$ & $0.267^{\mathbf{b}}$ & $0.55^{\mathbf{b}}$ & 0.718 & 0.282 & {$[32]$} \\
Iraq (North Baghdad) & 0.15 & 0.141 & 0.693 & $0.662^{\mathbf{b}}$ & $0.338^{\mathbf{b}}$ & {$[33]$} \\
Iran & $0.195^{\mathbf{b}}$ & $0.172^{\mathbf{b}}$ & $0.633^{\mathbf{b}}$ & 0.724 & 0.276 & {$[25]$} \\
\hline
\end{tabular}

${ }^{\mathrm{a}} \mathrm{P}<0.05 \quad{ }^{\mathrm{b}} \mathrm{P}<0.01 \quad{ }^{\mathrm{c}}$ Not tested 
Table 3. ABO and Rh (D) genotype in Omanis compared to other populations

\begin{tabular}{|c|c|c|c|c|c|c|c|c|c|c|}
\hline \multirow[t]{2}{*}{ Genotype } & \multicolumn{2}{|c|}{ Present study $^{\mathrm{E}}$} & \multicolumn{2}{|c|}{ Kuwait $^{\circ}$} & \multicolumn{2}{|c|}{$\operatorname{Iraq}^{\mathrm{E}}$} & \multicolumn{2}{|c|}{ Jordan $^{0}$} & \multicolumn{2}{|c|}{ Tanzania $^{\mathbf{E}}$} \\
\hline & $\mathrm{n}$ & $\%$ & $\mathrm{n}$ & $\%$ & $\mathrm{n}$ & $\%$ & $\mathrm{n}$ & $\%$ & $\mathrm{n}$ & $\%$ \\
\hline$A A$ & 76.86 & 2.25 & 4 & 3.97 & 28.53 & 2.25 & $6^{\mathrm{a}}$ & 5.714 & 45.89 & 2.53 \\
\hline$A O$ & 727.61 & 21.3 & 25 & 24.75 & 263.62 & 20.79 & $35^{\mathbf{b}}$ & 33.333 & 416.14 & 22.93 \\
\hline$B B$ & 66.95 & 1.96 & 3 & 2.97 & 24.98 & 1.97 & 1 & 0.953 & 26.136 & 1.44 \\
\hline BO & 679.1 & 19.88 & 20 & 19.80 & 246.88 & 19.47 & 14 & 13.333 & $314.07^{\mathrm{a}}$ & 17.3 \\
\hline$A B$ & 143.47 & 4.2 & $14^{\mathrm{b}}$ & 13.86 & 53.38 & 4.21 & $10^{\mathbf{b}}$ & 9.524 & 69.26 & 3.82 \\
\hline$O O$ & 1722.01 & 50.41 & $35^{\mathbf{b}}$ & 34.65 & 650.61 & 51.31 & $39^{\mathbf{b}}$ & 37.143 & 943.504 & 51.98 \\
\hline Total & 1416 & 100 & 101 & 100 & 1268 & 100 & 105 & 100 & 1815 & 100 \\
\hline$D D$ & 1727.47 & 50.57 & & $J T^{c}$ & $555.4^{\mathrm{b}}$ & 43.8 & & $N T^{\mathbf{c}}$ & $1305.17^{\mathbf{b}}$ & 71.91 \\
\hline$D d$ & 1403.98 & 41.1 & & $\mathrm{NT}^{\mathrm{c}}$ & $566.8^{\mathrm{a}}$ & 44.7 & & $N T^{\mathbf{c}}$ & $467.9^{\mathbf{b}}$ & 25.78 \\
\hline$d d$ & 284.55 & 8.33 & & $\mathrm{NT}^{\mathrm{c}}$ & $145.8^{\mathrm{b}}$ & 11.5 & & $N T^{\mathbf{c}}$ & $41.93^{\mathbf{b}}$ & 2.31 \\
\hline Total & 3416 & 100 & & & 1268 & 100 & & & 1815 & 100 \\
\hline
\end{tabular}

\section{Discussion}

A retrospective study was conducted on 3416 Omani blood donors to determine $\mathrm{ABO}$ and $\mathrm{Rh}$ (D) phenotype, allele frequencies and estimated genotypes. The data obtained from AFH which is located in the Oman's capital Muscat; however, blood drive campaign nature of the blood bank includes donors from different regions in Oman. Therefore, the samples were from a country wide basis and not restricted to one small area. Oman is a country of admixed ancestry of African, Asian and Caucasian. The blood group typing is very useful in genetic population $^{21}$, so the study of prevalence and frequencies should be carried out in every central and regional blood bank.

The $\mathrm{ABO}$ and $\mathrm{Rh}$ (D) ratio for Omani male to female is 96.84: 3.16. However, it showed significant difference $(P<0.01)$ from observed ratio 94.5:5.5 on a study conducted in Pakistan by Rehman and colleagues ${ }^{21}$. Present study targeted blood donors only and not the general population, which could explain such significant difference compared to Rehman and colleague's study. In addition, most of the samples in present study were collected from blood campaign mainly in military units where male donors were dominant. To rule out possible bias due to low number of female donors, we compared $\mathrm{ABO}$ and $\mathrm{Rh}$ (D) type of female gender $(n=108)$ in present study with study conducted by Al-Dughaishi and colleagues ${ }^{18}$ on larger number of Omani females $(n=1251)$. The statistical data showed no significant difference gender wise in ABO $(p=0.3190)$ and $\mathrm{Rh}(\mathrm{D})(p=$ 0.1483 ) types between both studies. Present study also showed no significant difference between Omani male and female blood donors with regard to ABO types $(p=0.9632)$ and $\mathrm{Rh}(\mathrm{D})$ types $(p=$ 0.2905).

The overall $\mathrm{ABO}$ distribution pattern in Omanis showed group $\mathrm{O}$ is the highest, which is similar to those reported in Saudi Arabia ${ }^{13}$, Kuwait ${ }^{22}$,

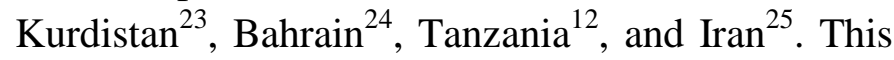
$\mathrm{ABO}$ distribution is different from those in Eastern (Jharkhand) and Northern (Punjab) India where type $\mathrm{B}$ is prevalent ${ }^{26-27}$ and Palestine ${ }^{28}$ and Jordan ${ }^{29}$ where type $\mathrm{A}$ is the commonest (Table 1). Rh (D) positive and negative phenotype frequencies vary between populations. Present study recorded Rh (D) 
positive frequency of $91.65 \%$ and $\mathrm{Rh}$ (D) negative frequency of $8.35 \%$. This is similar to some countries in the South Eastern Arabic Peninsula (Table 3). Rh (D) negative frequency in Oman is different from Palestine, Eastern India and Tanzania where its frequency is low (Table 1) and Switzerland $^{30}$ and Southwestern Ethiopia ${ }^{31}$ where its frequency is as high as $15 \%$ and $19.37 \%$ respectively.

As ABO blood group system has been widely studied and reported, we compared present study $A B O$ allele frequencies with those from other Asian, European and African populations. Historical $A B O$ and $D$ allele frequencies from healthy Omani population $(n=160)^{23}$ were reviewed and compared with present study. We found no significant difference between both studies $(p=0.8377)$, which means the frequencies remained the same despite possible naturalization during the last 30 years. A significant difference between Omani population and many other reviewed populations $(p<0.05$ or $<$ 0.01 ) with regard to $\mathrm{ABO}$ alleles were observed, except with Tanzania and Iraq where similarities were recorded ${ }^{12,13,22,25,30,32,33}$ (Table 2). The background of admixed ancestry of Omani population should be considered as a reason of such difference with other populations. Political turmoil in 1964, encouraged the migration of Omanis to return to their home country from Zanzibar ${ }^{34}$ which might explain the agreement in $A B O$ alleles ( $A$ and $O)$ data between Oman and Tanzania. Though Omani population showed agreement with Tanzania and Iraq with regard to $A B O$ alleles, but significant difference in the presence of $D$ allele were recorded (Table 2).

Based on genotype frequencies, we calculated expected $A A, A O, B B, B O, A B, O O, D D, D d$ and $d d$ frequencies in present study and compared it with observed or expected results of other populations (Table 3). There is no significant difference between Omani, Kuwaiti, Iraqi and Tanzanian with regard to $A A, A O$ and $B B$ genotypes whereas Jordanian showed statistical difference with $A A$ ( $p<$ $0.05), A O(p<0.01), A B(p<0.01)$ and $O O(p<0.01)$ genotypes. Tanzanian showed agreement with
Omani population except with $B O(p<0.05)$ genotype and $D D, D d$ and $d d(p<0.01)$ genotypes, whereas Iraqi showed difference only with regard to $D D(p<0.01), D d(p<0.05)$ and $d d(p<0.01)$ genotypes. The significance difference in $A B O$ and $R H D$ genotypes reflected in the fact that allele frequencies of specific type showed significant difference with these populations.

\section{Conclusion}

$\mathrm{ABO}$ and $\mathrm{Rh}$ (D) frequencies are similar to the historic study on healthy Omanis reported in 1987 with a small sample size. These recorded frequencies appear to be intermediate between some other countries. The commonest blood group in Omanis is $\mathrm{O}$ group while the $\mathrm{AB}$ group is the rarest. Our study could be of great help in transfusion service, geographical information, clinical studies with disease association and genetic studies. We recommend $\mathrm{ABO}$ and $\mathrm{Rh}(\mathrm{D})$ study on different regions in Oman to observe any diversity. Observed $\mathrm{ABO}$ and $\mathrm{Rh}$ (D) genotyping analysis are also required to assess the agreement of estimated genotypes in present study.

Acknowledgment: We thank Captain MudharNasib Bait Faraj and first lieutenant Hamed Mohammed Al Bahlouli, both of Armed Forces Hospital, Oman, for providing full support in data collection.

Authors' Contributions: MA contributed to experimental design, performed data analysis and prepared the manuscript. LA and TA collected the data. All authors read and approved the final manuscript.

Conflicts of Interest: The authors declare that they have no competing interests.

\section{Financial Support and Sponsorship: Nil}

Ethics Approval and Consent to Participate: Ethical approval obtained from Forces Medical Services Research Committee at Armed Forces Hospital (FMS - RC 3/2018). Gatekeeper consent form was given to the laboratory manager prior to data access. 


\section{References}

1. Gates MA, Wolpin BM, Cramer DW, Hankinson SE, Tworoger SS. ABO blood group and incidence of epithelial ovarian cancer. Int J Cancer. 2011;128(2):482-6.

2. Zouine S, Marnissi F, Otmani N, Bennani Othmani M, El Wafi M, Kojok K, et al. ABO blood groups in relation to breast carcinoma incidence and associated prognostic factors in Moroccan women. Med Oncol. 2016;33(7):67.

3. Khan MI, Micheal S, Akhtar F, Naveed A, Ahmed A, Qamar R. Association of ABO blood groups with glaucoma in the Pakistani population. Can J Ophthalmol. 2009;44(5): 582-6.

4. Liu J, Zhang S, Liu M, Wang Q, Shen H, Zhang Y. Distribution of $\mathrm{ABO} / \mathrm{Rh}$ blood groups and their association with hepatitis $\mathrm{B}$ virus infection in 3.8 million Chinese adults: A population-based cross-sectional study. $J$ Viral Hepat. 2018;25(4):401-11.

5. Sharif S, Anwar N, Farasat T, Naz S. ABO blood group frequency in Ischemic heart disease patients in Pakistani population. PJMS. 2014;30(3):593-5.

6. Ben Q, Wang K, Yuan Y, Li Z. Pancreatic cancer incidence and outcome in relation to ABO blood groups among Han Chinese patients: a case-control study. Int J Cancer. 2011;128(5):1179-86.

7. Kaffenberger SD, Morgan TM, Stratton KL, Boachie AM, Barocas DA, Chang SS, et al. ABO blood group is a predictor of survival in patients undergoing surgery for renal cell carcinoma. BJU Int. 2012;110(11 Pt B):E6416.

8. Stamatakos M, Kontzoglou K, Safioleas P, Safioleas C, Manti C, Safioleas M. Breast cancer incidence in Greek women in relation to ABO blood groups and $\mathrm{Rh}$ factor. Int Semin Surg Oncol. 2009;6:14.

9. Chavhan A, Jadhao R, Pawar S. The study of Allelic Frequency of ABO and Rh D Blood Group among the Banjara Population of
Akola District, Maharashtra, India.AOJA. 2012;8(2):71-3.

10. Kassahun Tesfaye, Petros Y, Andargie M. Frequency distribution of $\mathrm{ABO}$ and $\mathrm{Rh}$ (D) blood group alleles in Silte Zone, Ethiopia. The Egyptian Journal of Medical Human Genetics. 2015;16:71-6.

11. Kumar S, Modak PK, Ali H, K BS, Gusain VS, Roy R. A retrospective study: ABO and $\mathrm{Rh}$ phenotype blood group distribution among blood donors in H.N.B. Base Hospital, Srinagar, Uttarakhand, India. Journal of Family Medicine and Primary Care. 2018;7(1):34-8.

12. Jahanpour O, Pyuza JJ, Ntiyakunze EO, Mremi A, Shao ER. ABO and Rhesus blood group distribution and frequency among blood donors at Kilimanjaro Christian Medical Center, Moshi, Tanzania. BMC Res Notes. 2017;10(1):738.

13. Sarhan MA, Saleh KA, Bin-Dajem SM. Distribution of ABO blood groups and rhesus factor in Southwest Saudi Arabia. Saudi Med J. 2009;30(1):116-9.

14. Keramati MR, Shakibaei H, Kheiyyami MI, Ayatollahi H, Badiei Z, Samavati M, et al. Blood group antigens frequencies in the northeast of Iran. TransfusApher Sci. 2011;45(2):133-6.

15. Said N, Ben Ahmed F, Doghri A, Ghazouani E, Layouni S, Gritli N, et al. [The ABO system polymorphism in Tunisian blood donors]. Transfus Clin Biol. 2003;10(5):331-4.

16. Benalla A, Karim A, Trougouty N, Sidqi Z, Mekhfi H, Benajiba M. Distribution of ABO and $\mathrm{Rh}$ blood groups in the oriental region of Morocco. Mintage Journal of Pharmaceutical \& Medical Sciences. 2017;6(Suppl 2):5-7.

17. 2010 GCopHaE. Census 2010 final results Oman National Centre for Statistics and Information Oman 2010 [Available from: https://www.ncsi.gov.om/Elibrary/LibraryCon tentDoc/bar_Census\%20Final\%20Result\%20 2010_388bd9c6-a938-467d-8c92f6950cc1785f.pdf. 
18. Al-Dughaishi T, Al Harrasi Y, Al-Duhli M, Al-Rubkhi I, Al-Riyami N, Al Riyami A, et al. Red Cell Alloimmunization to Rhesus Antigen Among Pregnant Women Attending a Tertiary Care Hospital in Oman. Oman Med J. 2016;31(1):77-80.

19. Danubio ME, Anelli A. ABO, Rh(D) and haptoglobin distribution in a sample from the sultanate of Oman. International Journal of Anthropology. 1987;2(1):77-8.

20. Al-Riyami AZ, Al-Marhoobi A, Al-Hosni S, Al Mahrooqi S, Schmidt M, O'Brien S, et al. Prevalence of Red Blood Cell Major Blood Group Antigens and Phenotypes among Omani Blood Donors. Oman Med J. 2019;34(6):496-503.

21. Atta Ur Rehman, Rashid A, Malik S. Genetic Diversity at $\mathrm{ABO}$ and $\mathrm{Rh}$ (D) Loci in the Tribal Groups of Mohmand Agency (Federally Administered Tribal Areas), Pakistan. The Anthropologist. 2015;19(3): 679-83.

22. Al-Bustan S, El-Zawahri M, Al-Azmi D, AlBashir AA. Allele frequencies and molecular genotyping of the ABO blood group system in a Kuwaiti population. Int $J$ Hematol. 2002;75(2):147-53.

23. Jaff MS. ABO and rhesus blood group distribution in Kurds. $J$ Blood Med. 2010;1:143-6.

24. Al Arrayed S, Shome DK, Hafadh N, Amin S, Al-Mukhareq H, Al-Mulla M, et al. ABO Blood Group and Rhd Phenotypes in Bahrain: Results of Screening School Children and Blood Donors. Bahrain Medical Bulletin. 2001;23(3):112-5.

25. Maatoghi JT, Paridara M, Shoushtari MM, Kiani B, Nori B, Shahjahani $M$, et al. Distribution of $\mathrm{ABO}$ blood groups and rhesus factor in a Large Scale Study of different cities and ethnicities in Khuzestan province, Iran. Egyptian Journal of Medical Human Genetics. 2016;17(1):105-9.

26. Singh A, Srivastava RK, Deogharia KS, Singh KK. Distribution of $\mathrm{ABO}$ and $\mathrm{Rh}$ types in voluntary Blood donors in Jharkhand area as a study conducted by RIMS, Ranchi. J Family Med Prim Care. 2016;5(3):631-6.

27. Kaur H, Khanna A, Manjari M, Khanna M. Prevalence of $\mathrm{ABO}$ blood groups and rhesus $(\mathrm{Rh})$ factor in the population residing in and around Amritsar, Punjab (a 4-year study from June 2007 to June 2011). Asian J Transfus Sci. 2013;7(2):159.

28. EL-WahhabSkaik YA, El-Zyan NR. Spectrum of $\mathrm{ABO}$ and $\mathrm{Rh}(\mathrm{D})$ blood groups amongst the Palestinians students at al-Azhar University Gaza. Pakistan Journal of Medical Science. 2006;22(3):333-5.

29. Hanania SS, Hassawi DS, Irshaid NM. Allele Frequency and Molecular Genotypes of ABO blood group system in a Jordanian Population Journal of Medical Science 2007;7(1):51-8.

30. Volken T, Crawford RJ, Amar S, Mosimann E, Tschaggelar A, Taleghani BM. Blood Group Distribution in Switzerland - a Historical Comparison. Transfus Med Hemother. 2017;44(4):210-6.

31. Golassa L, Tsegaye A, Erko B, Mamo H. High rhesus (Rh(D)) negative frequency and ethnic-group based ABO blood group distribution in Ethiopia. BMC Res Notes. 2017;10(1):330.

32. Rahmani MTH, Maqsood A, Muhammad S, Shahida H, Aamir H, Nadia R. Determination of Weak "D" Antigen among Rhesus Negative Pakistani Blood Donors. Annals of PIMS. 2016;12(3):131-5.

33. Saleh SM, Abood AS. ABO and Rh (D) Blood Groups' Distribution and Gene Frequencies in North Baghdad PopulationIraq. International Journal of Scientific \& Engineering Research. 2016;7(8):581-4.

34. Dresch P, Piscatori JP. Monarchies and nations : globalisation and identity in the Arab states of the Gulf: London ; New York : I.B.; 2005. 